JIM

ISSN: 2183-0606

(CC BY 3.0)

Vol. 9, 1 (2021)

p. $1-24$

AM: Dec2020

SM: Apr2020

\title{
Expanding Innovation Through Challenging Organization Endowments
}

\author{
Steven C. Griggs ${ }^{1}$ \\ ${ }^{1}$ Faculty of Management University of Central Oklahoma, 100 North University Drive, Edmond, \\ Oklahoma, 73034, United States 1-405-974-5659 | sgriggs@uco.edu
}

\begin{abstract}
Radical innovation in mature or large organizations has been on the decline in recent years. Incremental innovation is the norm and few large organizations create evolutionary or radical innovative offerings. A reason for the lack of innovation in mature or large firms is based on management practices over the last several decades for pursuing sustainable competitive advantage that are affected by various biases. The resource-based view of the firm, open innovation, and design thinking are discussed, and resulting endowment effect biases are identified from literature and case studies from individual companies and industries. An innovation endowment effect framework is created to qualitatively assess strengths of various endowments. Various methodologies and processes are discussed to reduce the impact of endowment effect biases and increase radical innovation.
\end{abstract}

Keywords: Decision-making; Innovation; Product Development; Strategic Planning; Management Development; Resource Management; Endowment Effect; Sustainable Competitive Advantage.

Cite paper as: Griggs, S.C., (2021). Expanding Innovation Through Challenging Organization Endowments, Journal of Innovation Management, 9(1), 1-24.; DOI: https://doi.org/10.24840/2183-0606_009.001_0003

\section{Introduction}

The global competitive marketspace requires firms to continuously generate innovative new products for their perpetual survival and future growth (Potts, 2016). Innovative products can be considered radical, while others are evolutionary or incremental at best. Relevant radical products are desirable for creating a sustainable competitive advantage. Previous studies have shown that larger firms are unlikely to introduce radical new products (Ettlie and Rubenstein, 1987). Firm size was shown to be more strongly related to the implementation than initiation of innovation (Damanpour, 1992). Larger firms are more likely to successfully commercialize the limited number of radical new products that they do introduce, up to a certain point. This paper explores one reason for the lack of radical innovation in large and mature firms based on endowment effect bias.

Radical products and services are considered to be the purview of entrepreneurs and new start businesses over the last several decades. Kim, Lee, and Marschke (Kim, Lee and Marschke, 2009) have shown that small firms generate more patents per R\&D dollar. Patents per employee metric is a mixed result in small firms compared to larger firms depending on the industry. The patents per dollar for smaller firms has reduce in recent years, although still greater than large firms, could partially be explained by the increase in venture capital available to small firms. According to PitchBook Data, Inc., (PitchBook Data, Inc., 2019) the total value of venture capital deals increased from $\$ 27.4$ billion in 2009 to $\$ 136.5$ billion in 2019 . An approximately $500 \%$ increase in available capital could reduce the patent per dollar metric. However, a patent metric does not categorize the innovation as incremental, evolutionary, or radical. 
More recently, there is published work (Mote et al., 2016) that confirms the size of an organization is negatively correlated to innovation. Available resources, better perceived management, and visionary strategies of larger organizations were not found to be significant. Forés and Camisón (Forés and Camisón, 2016) find similar results with negative correlation of radical innovation to firm size. Forés and Camisón did find a positive correlated to incremental innovation when both knowledge accumulation and organization size increase. There appears to have been a shift in the 1990s and 2000s for larger firms to become less innovative. The reduction in radical innovation by larger firms could be the result of many factors. However, the timing coincides with corporations focusing more heavily on core competencies. Prahalad (Prahalad and Hamel, 1990) (Prahalad, 1993) argued that leveraging corporate resources was considered to be the enabler of profitable growth. Instead of restructuring the corporation, executives focused on identifying, cultivating, and exploiting core competencies.

The following decade focused on competencies from a different perspective related to the more important firm's capabilities. Capabilities being the ability to deliver new products and services efficiently, repeatedly and in sufficient volume (Smith, 2008). Capabilities are the knowledge and skills possessed by the firm to know how to use its resources effectively and efficiently. Capabilities based competencies focused on what the firm did well with its resources and concentrated on those activities. Potentially outsourcing those activities, in which the firm did not excel. Decision makers focused their resources and capabilities on what they believed would generate a competitive advantage. Those that were confirmed to be a competitive advantage they view as an endowment. Endowment being a quality or ability that the firm possesses that has value and is inherited by the firm to be used for its future. The inherited nature of the resource and capability results in the decision maker placing greater value on those resources and capabilities than they are actually worth. This over valuation of the endowments is a bias known as the Endowment Effect (Knetsch, 1989).

Radical innovation creation and value capture techniques emerged in the 2000s as codified in Chesbrough's Open Innovation concepts (Chesbrough, 2003) and Liedtka and Ogilivie's process for Design Thinking (Liedtka and Ogilvie, 2011). Open innovation argued for exploring and considering radical innovation external to the firm and internalize it or rely upon suppliers for the radical innovation elements of the firm's products or services. Design thinking is more of an internal process by which radical innovation is created, developed, and produced to meet a customer need. Both of these processes are knowledge or capabilities based approaches to creating and capturing the value for radical innovation. Open innovation and design thinking are also subject to various biases. It will be argued that the resource based view of the firm, open innovation, and design thinking all have claims to creating sustainable competitive advantage but also have endowment effect biases that can limit the innovation to be more incremental than radical. Maximizing the potential for radical innovation to create a sustainable competitive advantage requires the identification and minimization of various biases.

Organizations focused on their endowments of resources, capabilities, and existing marketspaces can explain the lack of radical innovation in mature larger organizations. Focusing on current endowments decreases the scope of opportunities that a firm will explore. These endowments reduce radical innovation but may have benefits to incremental innovation under certain conditions. Mature and larger firms operate and grow to large size based on being effective at doing the right things in supplying products and services to their intended marketspace. Once effective, the focus was on becoming efficient with operating the organization for a specific product line or service. Firms become effective and efficient by developing, accumulating, and codifying the resources, knowledge, personnel, and system to optimize the organization. These factors become 
the endowment of the organization and make it unique, preferably with a competitive advantage.

This paper adds to the scholarly work by applying endowment effect to innovation management. Three research questions are explored in this applied conceptual paper. (1) What are the endowments that influence decision makers pursuing innovation? (2) Are some endowments considered to be more valuable and thus stronger at influencing decision makers? And (3) how would a company or industry overcome endowment effect on their innovation pursuits?

The paper's methodology is to conduct a qualitative analysis of resources, capabilities and marketplace endowments along with radical innovation creation and value capture by: conducting a literature review of scholarly journals and appropriate seminal work; examine various theories pertaining to endowments and innovation; identify various firms and industries that exhibit endowment effect bias along with other cases and dataset on disruptive innovation; identify the detailed endowment biases from the examples; categories the endowment details; assess the relative strength of the endowment details; then create various options for mitigating the endowment effect biases to enable radical innovation. Further research topics are also discussed to continue scholarly understanding of endowment effect and innovation.

The various theories on resource-based view of the firm and several innovation processes that create more radical innovation are explored. Each theory is shown to create a strategy for competitive advantage through radical innovation. However, each is subject to various decisionmaking biases. Endowment effect biases were assessed based on the various innovation and competitive advantage theories. Examples at the firm level and industry level were identified and discussed to determine, in more detail than previous scholarly work, what the actual endowments are that impact innovation decision makers. These endowments were then characterized to qualitatively determine the strengthen each endowment may have on decision making pertaining to radical innovation creation and value capture.

The research methodology is structured to answer the three research questions based on elements of various resource and innovation value models to create sustainable competitive advantage. Several examples of endowment effects at the firm level and industry level are given. These examples suggest that endowments within the firm or industry can have various strengthens and the magnitude of the biases can be industry or firm dependent. The paper concludes with discussions on limitations of this research and future research for endowment effect bias applied to innovation management.

\section{Literature Review}

A review of scholarly work explored various theories in resources, capabilities, innovation processes, and decision maker biases to reject radical innovation in favor of incremental innovation. The strengths of resource-based view of the firm and innovation management processes of open innovation and design thinking used to create radical innovation for sustainable competitive advantage are examined. Various scholars also argue each of these are also subject to various biases that can result in the rejection of radical innovation in favor of incremental innovation. This paper will focus on the endowment effect biases impact to radical innovation creation and value capture. The literature review is summarized, and three research questions are identified.

A resource-based view of the firm became prominent starting with Wernerfelt's 1984 paper (Wernerfelt, 1984). In which he argues that firms should analyze their resources rather than their products for new strategic options. Porter (Porter, 1985) focused on the firm's value chain for sustained competitive advantage and included intangible as well as tangible resources. This reinforced Wernerfelt's position that resources contributed to the strategic options for a firm. 
Barney (Barney, 1986) argued that strategic resources that have to be obtained may erode any superior profits that could be obtained if they already possessed the resource. He also argued that analyzing the skills and capabilities of the firm could be a more accurate predictor than analyzing the competitive environment. Dierickx and Cool (Dierickx and Cool, 1989) added to the discussion on the sustainability of strategic resources by arguing that sustainability is dependent on how easy the assets could be substituted, imitated, or traded.

The potential for resources to generate a sustainable competitive advantage required a framework or theory by which to test the hypothesis. Barney (Barney, 1991) identified four empirical indicators for a firm to generate sustained competitive advantage. His Value, Rareness, Imperfect Imitability, and Non-substitutable (VRIN) framework provided an analytical for sustained competitive advantage. Barney also discusses that "sustained competitive advantage depends, in critical ways, on the resource endowments controlled by the firm." Conner (Conner, 1991) elevated the resource based-view of the firm arguing that it was actually a new theory of the firm. He argues that resource-based view of the firm focuses on the cost-to-copy attributes of the firm which is the source of economics rents and is the source of competitive advantage. Conner also suggests that hierarchies of resources may exist and should be considered as adding different levels of explanatory power to sustainable competitive advantage.

Contribution to the realization of sustainable competitive advantage based on resource based view of the firm was further expanded by Peteraf (Peteraf, 1993). Peteraf's cornerstones of competitive advantage argue that heterogeneity and imperfect mobility of resources coupled with ex ante limits to competition and ex post limits to competition ensure rents are attainable. The uncertainty of ex post limits to competition in a bounded rationality condition could lead to biased decision making based on expectations of future events having little impact. At the same time, Amit and Schoemaker (Amit and Schoemaker, 1993) contribution was focused more on capabilities, resource-market capabilities, and discretionary managerial decisions about resource development and deployment. They also argued that behavior decision bias and organizational implementation issues can reduce the economic rents of resources. Their definition of capabilities refers to "a firm's capacity to deploy resources, usually in combination, using organizational processes, to effect a desired end" distinguishes capabilities form resources in that capabilities are the effective use of resources and not a resource unto itself. Amit and Schoemaker emphasize the acknowledgement of bounded rationality that decision-makers are subject to with the uncertainty of the marketspace and uncertainty of innovation, competitors, and rules of the game.

Barney (Barney, 1995) updated his VRIN framework to include the capabilities aspect of resource based view for sustainable competitive advantage. The VRIO (value, rareness, imitability, and organization) model highlighted that the organization must be able to exploit the resources with their capabilities. This reinforces the knowledge-based aspects of exploiting resources and capabilities to deliver sustainable competitive advantage. Collis and Montgomery (Collis and Montgomery, 2008) looked externally to the market forces for determining value of the resource or capability. Scarcity, demand, and appropriability are required in the market for there to be value. They provide a five-point test to qualitatively assess the value. Test five "The test of competitive superiority: Whose resource is really better?" led to many companies engaging in "core competency" assessments to determine where they were superior. Collis and Montgomery point out that the core competence exercise "has too often become a "feel good" exercise that no one fails." This can be attributed to bounded rationality or several different biases.

Christensen's Innovator's Dilemma (Christensen, 1997) created a theory of disruptive innovation. He investigated how incumbent firms making superior products and services for a marketspace are replace by firms with less resources and capabilities. The difference is that the new entrant firm is 
focusing on different product and service attributes that "overserved customer" desire. Incumbents listen to customers, invest in the business, and build distinctive capabilities. This follows the resource-based view of the firm. Christensen's four major points are: (1) incumbents are improving along a trajectory of innovation, (2) the pace of sustained innovation overshoots customer needs, (3) incumbents have the capability to respond but fail to exploit it, and (4) incumbents flounder as a result of the disruption. These appear to be decision-making issues influence by decision-maker bias. Their bias is not only of their product but of the marketspace. Christensen and Raynor (Christensen and Raynor, 2003) argue that firms engage in sustaining innovation and introduce year-by-year incremental improvements to the same marketspace. Disruptive Theory identified an issue when firms rely upon their resources, capabilities, and marketspaces as endowments that may be replace by another firm's innovation applied to the product, marketspace, or totally new marketspace. King and Baatartogtokh (King and Baatartogtokh, 2015) empirical assessed the theory of disruption and found that all four points were present in a limited percentage. The overshot customer needs were highly overrated based on the empirical survey data. However, there was considerably more correlation with the other points.

The resource-based view of the firm was further criticized by Armstrong and Shimizu (Armstrong and Shimizu, 2007) who argued that when environments change quickly formerly valuable and inimitable resources become a source of "core-rigidities" that competitors are not burdened by. The result is the firm is subject to a sustainable competitive disadvantage resulting in negative performance. MIT Sloan School of Management faculty Michael Cusumano in a 2011 interview (Hopkins, 2011) discussed the need for firms to be agile in dynamic environments. This would lead firms to always question what capabilities to nurture in the firm. Kilingebiel and Rammer (Klingebiel and Rammer, 2014) argue that innovation performance is impacted by resource allocation to a broad range of innovative products. The breadth-based approach increases performance because it spreads bets on unproven endeavors. Additionally, limiting resource commitments by selecting out deteriorating projects prevents escalation of cost. Their focus on forced scarcity across multiple products enables a risk varying portfolio that includes higher-risk, higher-payoff opportunities. Nason and Wiklund (Nason and Wiklund, 2018) argue that VRIN resources have limited growth potential. Whereas, versatile resources are associated with higher growth. They argue versatile resources allow firms to recombine resources in novel ways to create growth. Cavaleri and Shabana (Cavaleri and Shabana, 2018) argue that radical innovation poses fewer strategic risks than incremental innovation. Radical innovation may also provide more competitive and financial advantages than well-established programs relying on incremental innovation.

The resource-based view of the firm is still a well utilized theory but the role of innovation in competitive advantage and firm success has increased. Two prominent approaches for radical innovation creation and value capture are "Open Innovation" and "Design Thinking." Open innovation is a paradigm described by Henry Chesbrough (Chesbrough, 2003) to break down the barriers of the firm to allow innovation to come from anywhere. Not only allow outside innovation to penetrate the traditionally closed off $R \& D$ groups but allow internal innovation to venture outside the company. This increases the pool of innovative ideas that can be incorporated into the firm's products and services. Slowinski et al., (Slowinski et al., 2009) point out various issues associated with looking externally for innovation to bring internally. Several of their key issues for this discussion are that it complicates: strategic planning, integrating external innovation into internal processes, allocating intellectual property rights between the firm and its external sources, and managing external relationships. It also requires strong dependence on external sources, creates need for new internal and external incentives, and requires cultural changes that may 
create internal resistance. Euchner (Euchner, 2010) reinforces that open innovation is a radical model with increasing importance and argues that three large changes are required for it to be successful. First is that the firm must modify its view of intellectual property (IP) and seek other sources of competitive advantage. Second open-source innovation requires a shift in control of new product development closer to the user. Third is open-source innovation requires a business model that can survive in a more open world.

Kovas et al., (Kovas, Looy and Cassiman, 2015) bibliometric review highlights the need for more theorical foundation for open innovation that include: transaction costs and value theory, resource-based view of the firm, dynamic capabilities approach, organizational learning theory, and real options theory. Positive aspects of open innovation are discussed. However, the detriments and impediments require assessment. Brunswicker and Chesbrough's (Brunswicker and Chesbrough, 2018) industry survey results show that a large majority of responding firms use the outside-in approach to open innovation, large firms are net takers of free knowledge flow and are concerned with IP protection. They also highlight project teams are reluctant to utilize large pools of knowledge fearing loss of control. Chesbrough et al., (Chesbrough, Lettl and Ritter, 2018) argue that successful open innovation requires there to be value creation and value capture by the actors. Thereby suggesting the firm cannot expect to capture all the value of the innovation otherwise the other actor will not participate. Bogers et al., (Bogers et al., 2019) argue that a dynamic capabilities framework is required to better understand strategic management of open innovation. They suggest the organization processes for sensing, seizing, and transforming capabilities are required for firms to reap the benefits of open innovation.

Alexy et al., (Alexy et al., 2018) suggest that open innovation strategies make some of the firms valuable resources available for free. They do argue that open innovation does make sense under two circumstances. The first one involves the desire to significantly improve the firm's performance by "opening resources reduces the firms cost basis while strongly increasing demand for their still proprietary resources." The second is that by being open can "reshape markets by weakening competitors, particularly rivalrous environments." Banerjee et al., (Banerjee et al., 2019) argue that larger firms have the power to decide what to collaborate on with smaller firms. They argue that "high-power leads to biases in judgements." They specifically identify status quo bias, endowment effect, and loss avoidance in prospect theory as the three cognitive domains in large firm biases.

Design Thinking is an internal process for creating and capturing the value of innovation. First popularized by Tim Brown (Brown, 2008) (Brown, 2009) from the renown US design firm IDEO as a process by which non-designers can understand how designers think when creating radically innovative new products and services. Liedtka and Ogilivie (Liedtka and Ogilvie, 2011) codified design thinking into a ten step process within four cycles. The four cycles are meant to answer four basic innovation uncertainties of (1) what is, (2) what if, (3) what wows, and (4) what works. Each cycle question starts with no ideas, concepts, prototypes, or finished products. They end with each as a decision to enter the next cycle. The ten steps are various tools that explore and create as many options in that cycle then those options are filtered to begin the next cycle with the expansion of concepts and the filtering of the concepts. The overall process has feedback loops to recalibrate at an earlier step in the process as new information is obtained to abandon or reset the process. The filtering stages where ideas and concepts are selected to move forward in the process are the most critical for radical innovation to mature. Various biases can influence which options are pursued and which ones rejected. Liedtka (Liedtka, 2015) challenged business scholars to explore the use of design thinking to create more innovative products and services by reducing cognitive biases. As with other innovative processes, strategies, plans, and resource 
allocation techniques decision makers are subject to various biases. Design thinking process can reduce some biases associated with creating ideas. However, the filtering phases of each cycle can allow biases to influence which ideas are selected to proceed through to the next cycle.

To summarize the literature review resource and capability-based strategies for competitive advantage are used and biases appear in the form of endowments in terms of resources, capabilities, and marketspaces. Marketspace endowments are apparent when reviewing disruptive innovation and the incumbent firm's fixation of the incremental and sustained technology improvement to meet a known customer or marketspace. Innovation creation and value capture, as discussed with open innovation and design thinking approaches, have been shown to have benefits for idea creation, but idea maturation and value capture are subject to biases in terms of resources, capabilities (or knowledge), and marketspaces. The literature discusses these three endowments in aggregate, but there is little in terms of what the actual endowments could be that influence decision makers to reject radical innovation and pursue more incremental innovation. This paper adds to the scholarly work by pursuing three basic questions. (1) what are the more detailed endowments that influence decision makers pursuing innovation, (2) are some endowments considered to be more valuable and thus stronger at influencing decision makers, and (3) how would a company or industry overcome endowment effect on their innovation pursuits?

\section{Endowments and Their Relevancy}

Endowments are a quality or ability that the firm possesses that has value and is inherited by the firm to be used for its future. Endowments for organizations are developed over time as a means for ensuring long term viability of the organization to continue in a competitive environment. The literature review identified sustainable competitive advantage for a firm is based on resources, capabilities, and/or innovation. The literature review also identified biases of firms in terms of their resources, capabilities, and marketspace endowments. These three categorizes of endowments have levels of distinctiveness for an organization to supply its marketspace with unique offerings and innovation based on market demands and the organizations competitive advantage. The organization develops over time those factors within the three endowment categories it believes will provide sustainable competitive advantage to continually supply the marketspace with desirable offerings. Once developed they are considered endowments by decision makers who have invested interest in them resulting in biases toward their endowments versus other alternatives. The vested interest in the endowments creates bias decision making, Endowment Effect, with regards to creating and capturing the value of incremental innovation forgoing radical innovation.

Endowment Effect, with regards to decision making, initiated with prospect theory developed by Kahneman and Tversky (Kahneman and Tversky, 1979) and Richard Thaler (Thaler, 1980) who conclude that losses from a reference position are systematically valued far more than commensurate gains. The theory was formally published by Knetsch (Knetsch, 1989) and Kahneman, Knetsch, and Thaler (Kahneman, Knetsch and Thaler, 1991). The concepts and theory of endowment effect that was applied to personal decision making is directly applicable to an organization, leadership, and product developer's decisions regarding innovation pursuits of mature or large firms. The overvaluation of a firm's endowments focuses their attention on innovation leveraging their current resource, capabilities, and marketspaces. Neglecting other opportunities that generate greater value.

The literature review found that scholars identified top level resources, capabilities, and marketspace categories but did not necessarily provide details into the endowments in these categories or identify which details may have greater influence or bias on decision making. These 
categories are explored from an innovation enabling perspective. Several companies and industries cases are discussed to further refine the characteristics of the endowments that influence innovation decision making. These characteristics are identified and qualitatively assessed to determine the relative strength of the various endowments toward creating a sustainable competitive advantage. The results are integrated into a radical innovation / endowment effect framework that can be used for assessing a firm or industry's biases based on marketspace, resources, or capabilities.

\subsection{Evidence of Innovation Impact due to Endowment Effect Decisions}

A firm's decision maker's response to endowment effect can lead to changes to overcome the biases against radical innovation, solidify an increment improvement strategy or a decision not to be innovative. Evidence of endowment effect on innovation decision makers in larger firms is provided by analyzing various examples using disruptive innovation dataset, several historical cases, and several current industry innovation challenges. Several emerging firms are included that are still unfolding regarding innovation decisions. The decision on whether to develop and implement radical innovation in these emerging firms has yet to be determined. These examples are used to identify the details within the endowments that are endowment effect biases against radical innovation. More detailed descriptions of these details will be described in subsequent sections.

\section{Disruptive Innovation Examples}

Clayton Christensen's Disruptive Innovation Theory was created by analyzing the computer disk drive industry (Christensen, 1997). Disruption of an incumbent firms occurs when a firm with substantial endowments incrementally innovates along a pre-described performance metric to a continuous market segment. They are replaced by a radically innovative low-end technology or business model innovation with different performance metrics, which appeals to different customer segments. Christensen's and Raynor's subsequent work evaluated seven-five companies and industries (Christensen and Raynor, 2003) and categorized how the entrant disrupted the incumbent. This can be used as the beginning of our discussion of details on endowments as it pertains to innovation. These seven-five examples were assessed based on understanding resources, capabilities, and marketspace endowments of the incumbents that appear to be devalued by a new entrant's technology, business model, or customer focus. Eventually the incumbent is replaced by the new entrant in the marketspace. The marketspace endowments that new entrants usually make irrelevant are: market product, price, place, promotion, and performance; customer base; competitors; strategy; business model; and competitive advantage. The resource endowments that new entrants make immaterial are: suppliers; property, plant and equipment; distribution channels; skilled work force, and product development. The capabilities the new entrant disparate are: policies and procedures; operations execution; systems knowledge; integration knowledge; and tacit knowledge. All examples in Christensen's and Raynor's database do not exhibit all these characteristics but many share the marketspace endowment characteristics.

Disruptive innovation assumes a radical innovation departure from the incumbent's technology, business model, customer base, or marketspace usually from a low-end perspective. The firms are initially small but quickly grow to potentially surpass the incumbent. Other examples will discuss the innovation endowments of large firms and industries beyond the disruptive innovation theory. These industries and firms will add to the list of endowment characteristics and provide other approaches in which radical innovation is not pursued.

\section{Xerox's Palo Alto Research Center}

Xerox's Palo Alto Research Center (PARC) was formed in 1970 to create the digital office of the 
future. In a remote location away from all the other Xerox copier business operating units they did just that (Smith and Alexander, 1999). PARC created the first personal computer, the first graphic oriented monitor (what would later be called windows), the first hand-held mouse, the first word processing program for not expert users, the first local area network, the first object-oriented programming language, the first laser printer, and the first spreadsheet. PARC invented most what the world takes for granted relating to computers, how humans interface with them, how computers communicate with each other, and the value-added functionality that the digital office of the future relies upon.

If Xerox commercialized all of their radical inventions, they would have been the first trilliondollar company decades ago. However, the endowment rich Xerox copier business, and even the computer company they bought, rejected the radical innovation of the office of the future invented at PARC. Xerox PARC developed systems, integration, and tacit knowledge and were years ahead of any perceived competitors. Xerox current operations overvalued their resources and marketspace endowments beyond anything they saw in the office of the future.

Trillions of dollars in value was unrealized due to endowment effect biases from Xerox's operating units. Years later Steve Jobs of Apple was touring PARC and ended up licensing windows and the mouse from PARC (Gallo, 2011). Xerox is a primary example of endowment effect and its impact on pursuing radical innovation. Even after they already created it. PARC created tremendous tacit knowledge, integration knowledge, systems knowledge, product development, and skilled workforce which they could use to continue the maturation and further develop radical innovation. Unfortunately, the incumbent business units would not accept the radical innovation since their resources, capabilities and marketspace endowments were valued more highly than a possible future that PARC created.

\section{Lockheed Martin Skunk Works}

The Lockheed Martin Skunk Works has been the leader in radical innovation in the aerospace industry since 1943. They developed the first operational jet fighter P-80, SR-71 Mach 3+ surveillance aircraft, the U-2 surveillance aircraft, F-117 first stealth weapons delivery aircraft, and a variety of other firsts in aerospace technologies and products. Although they were a separate division of a large aerospace firm, their founder, Kelly Johnson, limited their resources and created an environment of scarcity which required them to be highly inventive (Rich and Janos, 1994). As an example, the first Skunk Works facility was a rented circus tent erected in the parking lot of Lockheed Martin's Burbank facility. Operationally, Kelly Johnson's 14 rules for program management is based on rapid response decision making, minimal paperwork, and minimal processes.

By rejecting the Lockheed Martin operating ecosystem, the Skunk Works created and produced the technology and products for limited production runs (generally under 100 vehicles). The advanced technologies they produced were then used later by Lockheed Martin's large production run operating units. The Skunk Works operating as a separate division and maintaining the environment of scarcity, even when Lockheed Martin is the largest defense contractor, combined with a creative tension culture has enable it to produce radical innovation for over 75 years.

The Skunk Works focus on their capabilities and continually improved the capabilities, systems integration, and tacit knowledge drove their success in developing radical innovation. Their culture of scarcity did not create endowments in resources except in product development and skilled workforce. They also pursued other marketspaces and business models based on changing customers and their customer needs. For over 75 years the Skunk Works has produce radical innovation by purposefully advancing their capabilities without overvaluing any of their resources, 
capabilities, or marketspace. They never viewed the capabilities, resources, or marketspaces as endowments. The culture of scarcity and being in a highly competitive industry ensures that the Skunk Works will continue to develop and produce radical innovation.

\section{Healthcare Services}

Healthcare services is an industry that is currently undergoing radical innovation in response to patients. Medical devices, pharmaceuticals, surgery, and just about anything associate with the treatment of patience has seen great advances over the past four decades. Healthcare services are another matter. The policies and procedures created by hospitals and doctor's offices are based on efficiency of the operation and seeing as many patience as possible. Appointments are often weeks in advance and urgent or convenient care is only available in emergency rooms. The systems healthcare services created were for efficiency of the hospital or doctor's office and the patient need for non-emergency, but urgent care went unanswered by healthcare services (Kaissi, Shay and Roscoe, 2016). Hospitals and doctor offices overvalued their capabilities and resources and believed they had a monopoly on the patient marketspace. Patient needs in immediate but non-emergency situations were ignored.

Radical innovation in patient care was developed by standalone urgent care centers and retail clinics such as CVS, Walgreens, Walmart, and Target. They provided the radical innovation in healthcare services that patients needed-urgent or convenient care. They considered the immediate needs of patients for treatment of colds, flu, sprains, x-rays, and a variety of other immediate need services that were non-life-threatening. After a decade of retail clinics and urgent care centers filling the need, hospitals are beginning to create urgent care centers affiliates with the hospital, either on hospital property or at remote convenient locations. Whether hospitals and doctor offices will fully adopt the urgent and convenient care model in an affordable way is yet to be determined. Based on their current endowment bias toward large costly facilities and policy and procedure driven business models, the timely and affordable aspects of urgent and convenient care are probably unlikely to survive their hospital-first efficiency model in the long run.

\section{Cable Television}

Cable television providers are in an industry that is currently experiencing two radical innovations. The first is cable companies have experience subscribers abandoning the paid bundled content in favor of various streaming services (Tefertiller, 2018). Comcast Chief Executive Officer Brian Roberts stated that it was not of concern and it plays into their strengths, as reported by Reuters, July 25, 2019 (Coster and Vengattil, 2019). Roberts stated that they may be losing cable television subscribers, but they are obtaining more high margin broadband internet users. This response is based on his concept of the value of their endowments.

Cable company endowments are based on their physical hardware and in their contract negotiation skills. Cable companies have local government negotiated contracts to provide cable service to their community. The local government grants them a monopoly for their community in exchange for a percentage of the review the cable company receives or a flat fee. Once the contract is obtained the cable company hardwires the community and generally has no competition for the life of the contract. Cable companies also negotiate with producers, studios, and other television content generators for the rights to supply the cable company subscribers with content bundled together in an affordable monthly subscription. Content generators are obtaining more bargaining power due to alternative streaming capability. The margins on cable company content packages is being reduced due to alternative options. However, cable provided internet access through their hardwire is still more reliable and faster than other options. Cable companies high 
margin internet cable service has been an unintended fall out of the monopoly given to them by the local government. In most cases, cable internet access has the highest broadband data transfer rates that are affordable.

The second radical innovation is high speed wireless surpassing cable in internet access speed. $5 \mathrm{G}$ wireless infrastructure is expected to support high speed internet access at speeds equal to or beyond cable companies' top speeds. When this occurs cable companies' monopoly on high-speed broadband internet will be overvalued. Current developing $5 \mathrm{G}$ technology demonstrations are in the $27 \mathrm{~Gb} / \mathrm{s}$ class of data transfer rates (Patzold, 2019) which is 27 times that of the current fastest cable internet speed. Initial release of $5 \mathrm{G}$ wireless will be limited to $1-5 \mathrm{~Gb} / \mathrm{s}$ but future data transfer rates will make cable hardwire obsolete.

Cable companies' future is uncertain. The endowment effect may be the downfall of cable companies in which cellular phone providers may replace content delivery and internet access seamlessly for consumers. Other delivery providers such as Netflix and Amazon Web Services not only have large bundled stream services of content generated by many studios, production firms, producers, and television stations, but they are also generating their own content only available on their platform. Currently there is no indication that cable companies are starting to produce their own content. Cable companies' endowments of contract negotiations, hardwire infrastructure, distribution channels, PP\&E, business model, and competitors may become obsolete in the next decade.

\section{Uber Technologies}

Uber ride-hailing service pursued a radical departure from owning or renting your own car. It began in 2010 as a ride-hailing service similar to a taxi with additional information for the customer that included reviews of the drive, their location and approximate pick up time, and pre-paid, non-cash transactions. Uber and other companies engaged in ride-sharing are changing the behaviors of consumers (Muller, 2020). Uber's business model provided limited capital investment, flexible contract employee-based workforce, reduce cost due to not needing to procure taxi medallions to operate in specific geographic areas, the ability to scale globally, and reduce liability. Recently they expanded their services to include food and freight delivery.

Uber developed an integrated platform that changed the way consumer viewed hired driving services. Taxi service endowments of product, price, competitors, business model, competitive advantage, PP\&E distribution channel, policies and procedures, and operations execution were made obsolete. Local governments are beginning to take legal action or identifying potential rents that could be collected for Uber or their contract employees. This could raise prices, which are currently lower than taxi fares. However, the additional information that Uber provides on the driver and other services may still be a sustainable competitive advantage for Uber.

\section{Tesla Motors}

Tesla Motors radically deviated from other car manufacturers in terms of resources, capabilities, and marketspace endowments. The electric vehicle manufacturer's founder and the original engineering team did not have car industry experience (Van Den Steen, 2015). They assembled a team of specialist from Silicon Valley to give Tesla automobiles the innovation edge Elon Musk desired. Tesla Motors would only produce electric automobiles. Whereas, other car manufacturer's electric car offering was a minor subset of the internal combustion (IC) engine product lines. This eliminated the need for systems, integration, and tacit knowledge in IC power train and supporting systems. It also reduces the requirements of continuous mileage-based service and power train repair of components and systems. Tesla relied more heavily on open innovation that the rest of 
automobile industry. The subsequent product development, skilled workforce, and property plant and equipment resources were not required. Thereby reducing the footprint of the total factory space for automobile assembly. In addition, suppliers normally required to deliver IC based power trains and related systems were also not required. The all electric design did require innovation pertaining to battery design to obtain the desired range and vehicle performance the company desired. However, the radical reduction in the number of parts in the vehicle resulted in increased reliability.

Tesla also executed a Blue Ocean Strategy as discussed by Kim and Mauborgne (Kim and Mauborgne, 2005) by doing the complete opposite of the industries marketspace endowments. Tesla replaced dealerships, salesperson haggling, large marketing expenses, large media advertising, and integrated dealership service departments with direct-to-consumer sales, no-haggle policy, low marketing expenses, social networking, vehicle as software platform, and reduce servicing needs (Rothaermel, 2020).

Tesla's concept of radically designing, manufacturing, selling, and servicing automobiles made the endowments of other established automobile manufacturers irrelevant in the electric automobile marketspace. In addition, the marketspace expectation of electric cars was drastically altered from being small, cheap looking, low performance, limited range vehicle to an elegant, high performance, exception range, high technology platform. Tesla's endowment destroying approach in electric automobiles is unmatched to date. If Tesla expanded into IC drive train vehicles would they be successful, or would their endowments prevent that option?

\section{Endowment Effect Evidence Summary}

Evidence exists for endowment effect biases to impact the creation and value capture of radical innovation in various large firms and industries. Resources, capabilities, and marketspace endowments have characteristics that are more prone to endowment effect biases in certain companies and industries versus others. Disruptive innovation firms neutralize incumbent marketspace endowments with inferior resources and capabilities, but quickly develop new resources and capabilities that reinforces the new marketspace shift. Over time, the incumbent firms once prized resource, capability, and marketspace endowments become irrelevant.

Xerox and Lockheed Martin separated the innovation creation and value capture responsibilities for the firm into separate divisions outside the influence of operations. Xerox's PARC and Lockheed Martin Skunk Works both create radical innovation. However, the Skunk Works has a limited value capture capability that PARC did not. That limited value capture capability provided evidence of innovation success that then was transitioned into main operations. PARC failed to overcome main operations endowments and the executive staff of Xerox did not instigate transition of the innovation into operations.

Healthcare and cable industries endowments focused on policies and procedures, operations execution, PP\&E, and skilled work force. Along with a well-entrenched customer base, competitors, and business model they had been operating with little change in the industry. Superior diagnostics and treatment innovation in healthcare was created. However, providers sacrificed customer service and availability to their regular service provider to drive efficiency and profits. The status quo of their operation allowed for little radical innovation directed toward their customers need for care. Geographic monopolies of cable companies and low-quality endowments allowed for ample areas for innovators to radically change the marketspace by developing capabilities and resources cable companies ignored.

Uber and Tesla demonstrated that ignoring the endowments of an industry and redefining the endowments for success small companies can create radical industry changing innovation. Uber 
created a radical person, food, and freight delivery service platform. Tesla created a radical product, usage, purchasing, service, and business model platform. Both have governmental and legal challenges as incumbents respond to radical innovation which makes their endowments irrelevant. Resource, capability, and marketspace endowments have various characteristics that have more relevancy in one industry over another. Assessing the characteristics of resource, capability, and marketspace endowments, in aggregate, and qualitatively grouping those endowment characteristics will be the presented. An innovation endowment effect framework was developed to determine strengths of endowments and their corresponding impact to radical innovation decision making.

\subsection{Marketspace Endowment Perspective}

Marketspace endowments have characteristics that firms rely on for sustainable competitive advantage. The marketing mix (product, price, place, promotion, and performance) is the most basic of factors that many organizations use to distinguish their offering from their competitors. Companies create unique blends of this mix to distinguish their products from others. However, in most cases these are easily imitated. The specific customer base a company chooses to supply products and services to is another factor of uniqueness that focuses the organization on what factors of the product or service they will concentrate on to satisfy their customer base. Incumbent firms continuously offer incremental innovation to their existing customer base. The organization's competitors further define the uniqueness require to be competitive taking the competitors offering into consideration. Especially if they believe their competitors will always produce an inferior product offering. The strategy and business model the organization choses to utilize will set the stage for defining the competitive advantage required to ensure long term relevancy of the organization's superiority offering for a particular marketspace. The competitive advantage desired defines the overarching need for resources and capabilities to create the competitive advantage for relevant long-term uniqueness that will ensure the viability of the organization in a competitive marketspace. Once embedded in a marketspace an organization claims some ownership to that marketspace. Mature and large firms develop resource and capabilities over years or decades to provide the uniqueness deemed necessary for longevity.

\subsection{Resources}

The firm's resources are selected to product the products or services with the desire competitive advantage. Resources are developed over time from a new start company to a growth company to a mature or large company. Various factors are considered in a company's make or buy decision. Value added activities are internalized and others are contracted to suppliers. The right suppliers are resources to the organization, especially if through contracting or other arrangements they do not supply any other competitors in the marketspaces in which the organization competes.

Property, plant, and equipment (PP\&E) are resources selected to be efficient in the production and servicing of the offering to the marketspace. The desire for efficiency drives the selection of PP\&E to be honed to produce those products that have a competitive advantage. The efficiency driven selection of PP\&E also creates a manufacturing system which prefers not to deviate for the intended operating optimization. This optimization limits permutations and thereby restricts future usage of the PP\&E to incremental changes in the current product line.

Distribution Channels for our discussion is listed as a resource when they enable some aspect of competitive advantage. Distribution channels that are easy to imitate and are not protected by legal or contracting methods may be adequate but would not be considered a competitive advantage. However, various companies (Walmart, Amazon, Dell, etc.) grew and rely heavily on their distribution channels as one of their primary resources for competitive advantage. Companies 
that rely on their distribution channels view this endowment as one to protect even when other distribution channels appear to be superior.

Skilled Workforce resources are employees with specialized knowledge, training, experience, or problem-solving mindset to perform more complex physical or mental tasks than a routine unskilled labor. Skilled labor generally has higher education and expertise in the domain through formal education, training, or work experience. Skilled workers are less likely to be replace with automated systems due to the adaptability of the workers to variability of their tasks or the observing, assessing, and instantaneous decision making is not easily automated. Higher skill levels and the specialized education, training, or decision-making skills can be an endowment to the organization. Especially for organization which make complex products.

Product Development combines the skilled product development work force with an internal system dedicated to the creation, exploration, definition, maturation, prototyping, and commercialization of ideas. This endowment is part dedicated product development specialized resources (equipment, people, processes, etc.) and part capability knowledge skills pertaining to generation and maturing products from inception to the point of mass production. It is categorized as a resource in this case from the perspective of the specialized computers, software, laboratory, rapid prototyping, specialized tooling, and facilities that are not dedicated to standard operations and have no other use than to assist in product development.

\subsection{Capabilities}

A firm's capabilities differ from resources in that resources are assets that exist but have limited value to the firm unless they are used effectively and efficiently. Organization capabilities are knowing what to do with the resources, to supply marketspaces with goods or services, and to ensure new products and services can be created to expand the organizations offerings. Capabilities are the knowledge that makes it all work. Some knowledge-based capabilities can be easily obtained, others can take decades to develop in certain industries. They are all endowments that emphasize the uniqueness of the organization. Capabilities that are not easy to codify are also those capabilities that are harder for competitors to duplicate, imitate, or rend obsolete.

Policies and procedures are well documented codifiable processes and decision-making rules that ensure efficiency is obtained in operation of the organization. Policies and procedures are to ensure no deviation from intended standardization occurs for higher quality and ease of monitoring the overall operation and subunits. Organizations are driven to standardize by seeking ISO (International Organization of Standards) 9001, 14001, and other certifications. Being certified for various interests by ISO is an endowment that is required to be considered as a supplier in various industries. Once obtained, organizations desire to keep the certification and resist any change that could impact their certifications.

Operations Execution is organizing of internal production process, either for products or services. The flow of work in progress from inbound logistics to outbound logistics is part of operations execution. The placement of machinery, job tasks, flow from one cell to another, make or buy decisions, supplier and distribution selection and interface requirements are all part of the knowledge based by which an organization decides what to make/do and what to buy. These decisions are not always codifiable. However, once the decision is made the result may become a policy or procedure that is less likely to be changed. Operations execution knowledge is an endowment for organizations that seem to continually approach operations in way no matter what the product or service is being performed.

Systems knowledge capability for our discussion is the ability to have parts of a mechanism or an interconnection of independent items to form a network for the accomplishment of something. 
This can be in reference to the organization, its suppliers and distribution channels, or it could be in reference to the product or service the organization provides to its customers. This requires a good understanding of the inner workings of each element in the systems and how it interfaces with other elements. System knowledge also assumes the capability of controlling the overall processes the system will employ. This suggest that any unknowns or perturbations to the norm are well understood and can be characterized. Systems knowledge is hard to codify, but once the system has been created codification can be created for that particular system.

Integration knowledge could be construed as meaning the same as systems knowledge. For our purposes, integration knowledge is more of an art than systems knowledge. Integration knowledge is the understanding of different combination of elements that can produce similar results. The combinations have benefits and detriments to accomplish the overall goal. The multiple concepts that can be created are evaluated for various combinations of the benefits and detriments until an acceptable solution is determined. As this suggests, integration knowledge is required when there is more uncertainty with a final decision on an optimal solution, which is dependent on the particular combination of benefits and detriments for a marketspace. Integration knowledge can be considered as a long-term capability development knowledge source for innovation. This knowledge base is more difficult to codify.

Tacit Knowledge is non-codifiable knowledge that an individual or organization possesses. Usually associated with extraordinarily complex, heavily integrated, systems which have numerous solutions that are acceptable. Military aircraft manufacturers, pharmaceutical, and information technology and communications organizations are examples or organizations that possess tacit knowledge. Organizational level tacit knowledge in an industry that creates ideas and develops concepts to bring innovation to the marketspace can bring hundreds of different knowledge disciplines together to create new products. The organization and its participants just know what to do, with or without policies and procedures. These tacit knowledge driven companies develop that capability over decades, and it is difficult for competitors to replicate or imitate the organizations capabilities without decades of experience developing similar products.

\subsection{A Framework for Assessment of Endowment Effects Impact to Innovation}

Various endowments have been identified and an assessment was conducted to determine the strength that these endowments. A framework was created to quantify the strength of an endowment to create sustainable competitive advantage and its perceived strength as a bias against radical innovation. The literature review provided various models for characteristics of resources and capabilities that provide sustainable competitive advantage (Wernerfelt, 1984) (Porter, 1985) (Barney, 1991)(Amit and Schoemaker, 1993)(Barney, 1995)(Collis and Montgomery, 2008). These characteristics are: valuable, rare, imperfectly imitable, non-substitutable, organizationally exploitable, depreciate slowly, appropriable, better than competitors, create value, capture value, and company controls the value versus employees, suppliers, or customers. Increased strength in these characteristics creates the competitive advantage thereby creating an endowment. The framework also recognizes that there are benefits and cost to creating endowments which can also explain the endowment effect due to time, cost, legacy, or previous performance expectations. These endowments also create biases against radical innovation the biases strength is qualitatively proportional to the endowment strength in maintaining incremental innovation.

An Innovation / Endowment Effect Frame, Figure 1, was created based on the previous discussion. This framework provides resolve to the first two research questions. Details as to which endowments impact creation and value capture of radical innovation are identified and a qualitatively generated relative strength of the endowment is provided based on characteristics. 


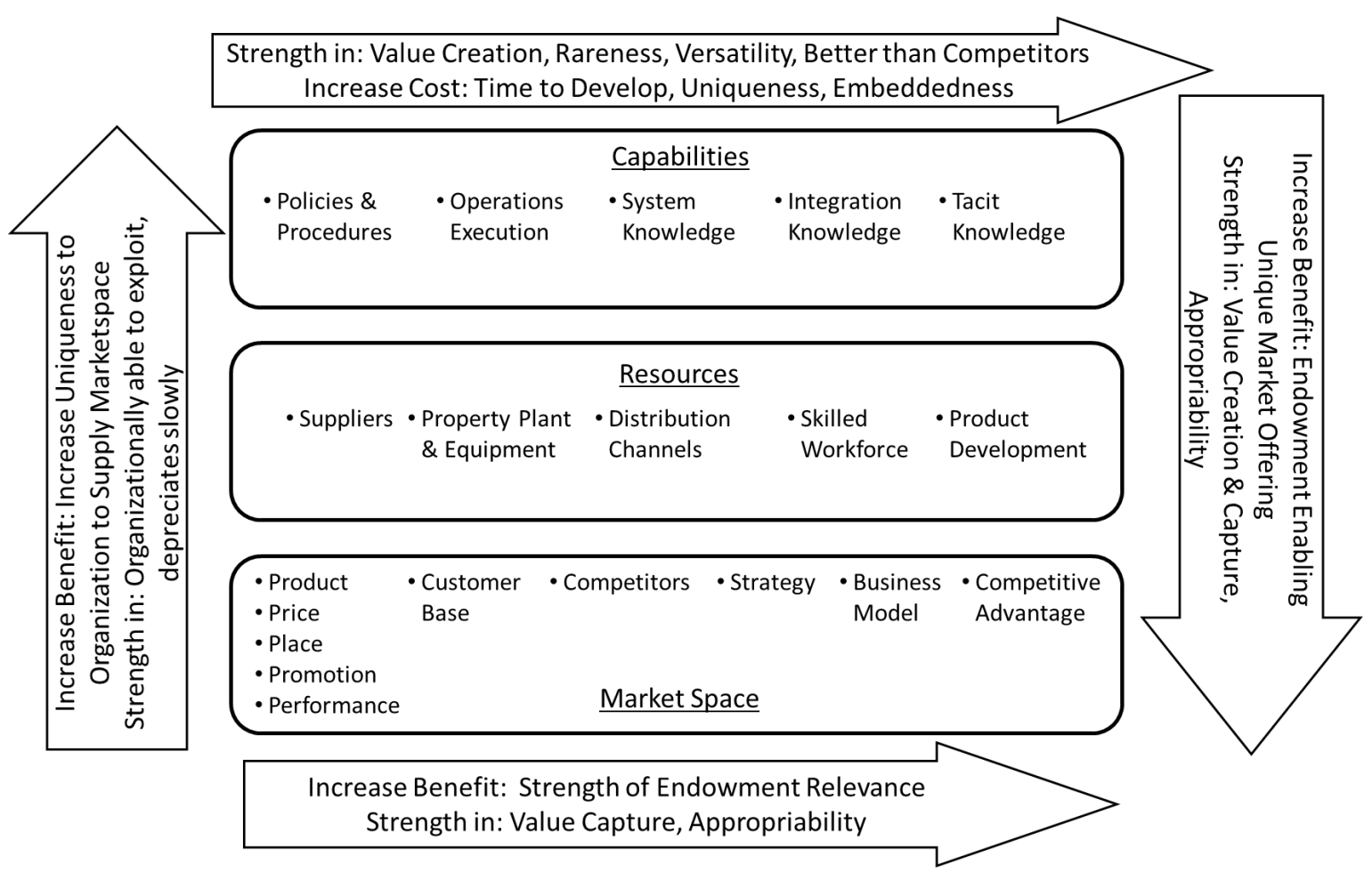

Figure 1. Innovation/ Endowment Effect Framework: Endowments of Organizations to Provide a Unique Offering to a Marketspace

The relative strength in the endowment proceed from left to right in the appropriate capabilities, resources, or marketspace swim lane. Relevant tacit knowledge has far more impact to value creation and radical innovation generation than policies and procedures. Product development has far more impact to radical innovation than suppliers to the organization. In addition, Competitive advantage has far more impact to capturing value from radical innovation in the marketspace than the $5 \mathrm{Ps}$. There is an increase benefit and cost to creating and maintaining these endowments. Creating these endowments requires time to develop, creating unique knowledge, resources, or capabilities, and embedding the endowments in the organization. The benefit is that there is sustainable competitive advantage if the organization continues to pursue radical innovation and not succumb to incremental innovation. Strength in the endowments impact to radical innovation is also is based on the endowment type. Capabilities have far more impact to innovation that marketspace. The organization uniqueness to create sustainable competitive advantage is in its ability to exploit the marketspace, resources, and capabilities at the same time ensuring that they depreciate slowly. The capabilities and knowledge skills of the organization are the driving force behind the value creation and capture of radical innovation. Relative strength of endowments can be qualitatively assessed based on weakest strength is in the lower left and greatest strength in the upper right of Figure 1. These perceived strengths coincide with cost, effort, and internalization of the endowment. The reliance on the endowment or overvaluation of the endowment is what creates the endowment effect bias than hampers radical innovation in lieu of incremental innovation.

Resources, capabilities, open innovation, and design thinking all have potential for creating sustainable competitive advantage. However, biases are present in the implementation each of these theories, techniques, and processes which limits the exploration of possibilities to incremental innovation. Endowments that limit radical innovation and their relative strength to hinder innovation has been identified in a new framework. Knowledge of biases and the forms that they 
take can help decision makers assess their innovation creation and value capture choices. Awareness may be enough to increase radical innovation creation and value capture. However, biases are not easily overcome in most circumstance. Actively and consciously challenging endowments while exploring possibilities of value creation and value capture from radical innovation is a must in the global competitive marketspace.

\section{Overcoming Endowment Effect to Increase Relevant Radical Innovation}

Endowments have varying degrees of strength and relevance to bring unique products and services with a competitive advantage to the marketspace, Figure 1 . These endowments also have differing costs to develop and embed within the firm for long-term relevancy. The endowments that are most unique required the most time and effort to develop are generally the center of what drives the organizations innovative and operational system to provide superior products to their marketspace. Integration and tacit knowledge and product development resources are relied upon for developing new unique value-added products and services. Those endowments are viewed as what enabled the organization to become what it is and makes it successful.

Entrepreneurial, start-up, and small companies have few endowments and are not bound to existing marketspaces, resources, and capabilities. They can develop these based on where they see opportunities and explore what mix of marketspaces, resources, and capabilities will be the most effective and efficient in creating long-term growth. A large and mature company could exhibit a start-up mentality and explore new possibilities using Lockheed Martin Skunk Works as an example. However, the endowment effect will always instill a bias toward what they already have in terms of existing marketspaces, resources, and capabilities. Endowments can still have great value in creating incremental innovation. The key is to determine which ones will allow evolutionary or radical innovation and which ones do not?

Decision makers in large or mature companies can use a variety of exercises to challenge the incremental innovation driven biases of endowment effect. These exercises can be characterized by two main goals. One is to stimulate new ideas for product, service, and marketspace perspective and innovation creation. The second is to create an environment of scarcity to provide the environment of how the company should create, develop, produce, and distribute to an existing or new marketspace thereby capturing the value of the innovation. The technique is to ask challenging questions and seek objective answers regarding endowments by employing innovative solutions regardless of endowments. Complete mitigation of the endowment effect bias is optimistic. However, the challenge of the endowments will make decision makers aware of the cost of the bias in terms of lost opportunities by not pursuing radical innovation.

\subsection{Innovation Idea Generation}

Creating new ideas by challenging the endowments begins with acknowledging that the endowments are the result of effectively and efficiently commercializing an original idea. When the company was first created it had little resources and acquired resources for the purpose of creating a perpetual company. Over time, overabundant resources, capabilities, and potentially marketspaces from the original business idea made the company inefficient and potentially ineffective in pursuing new radical opportunities. Global competitors can imitate or leap beyond a mature company's products with increasing speed rendering endowments obsolete.

Challenging endowments should be pursued in progressively more challenging exercises to gradually introduce concepts that expose the negative impact to the firm due to the over valuation of their endowments. The purpose of the exercises is to overcome biases and rationally evaluate 
lost opportunities. Starting with the most challenging exercise can create a defensive position of the bias decision makers in favor of their endowments. The severity of the defensive position may make change extremely difficult.

\subsection{Idea Generation by Challenging Endowments}

Idea generation should begin by assuming your products or services are/or will be commoditized. The company can either compete or abandon and seek a new industry. Schumpeter (Schumpeter, 1975) referred to this as "Creative Destruction." His macroeconomic recommendation of incessantly destroying the old and incessantly creating the new are equally relevant for a firm in a global competitive marketspace. What marketspaces, resources, or capabilities are fixated on the products as the commoditize? How valuable are they if you competitor's resources and capabilities are more modern or efficient? Are you better off without them and starting over to win a commodity battle? Which endowments would you get rid of in a commodity situation? If you are not assessing these questions, then your products and services will shortly be commoditized, and your endowments will greatly loss their value as an asset that provides superior profits. If a commodity battle is unattractive then employing your resources and capabilities to a new industry may be the right choice.

The second idea generation exercise for challenging endowments it to evaluate how you are measuring the performance of your products and services from the marketspace perspective. Innovation Disruption (Christensen, 1997) is most potent when an incumbent firm's industry measures their products and services by one measurand of primary interest to the intended customer. The overserved marketspace customers seek other performance measurands in their decision making. Incumbents are replaced by entrepreneurial, smaller, or more innovative companies who see the desire for new performance measurands and create offerings for those customers. How would your endowments change if you assumed that your product or services performance measurands where $180^{\circ}$ out of phase with what the market desired? If your product or service could be described by 25 different characteristics and your company's resources, capabilities, and marketspace focus is fixated on just one, what happens to the value of your endowments if the market shifts to any or a mix of the other characteristics? Can your endowments adjust to a change in the industry performance measurands?

The third idea generation exercise for challenging endowments relates to reassessing the resources and capabilities and totally abandon the marketspace endowment. Even your competitive advantage. What would you develop and produce to create a new competitive advantage in a new industry or marketspace? What resources and capabilities would you need? Which ones do you not need? What endowments are holding you back from pursuing new opportunities? This deleveraging of your endowments is the most challenging to decision makers with endowment effect bias. It requires decision makers to accept the possibility that everything the firm has contributes no value toward their future. Leveraging your endowments hampers innovation because it fixates on the past instead of exploring the future.

\subsection{Innovation by Creating an Environment of Scarcity}

Entrepreneurial, start-up, or small firms have limited endowments if any. They suffer from and are not hampered by endowments. They can be highly innovative in developing new products and services while making do with the little resources they do have. They apply combinations of scare resources to solve problems and pursue new opportunities, referred to as "bricolage" (Senyard et al., 2014). They can pursue make/buy decisions that endowment biased firms do not. They can also make thoughtful decisions as to what they want to make and do internally and exactly 
what resources, capabilities, and marketspaces they want to develop and specialize in for the long term. Creating an environment of scarcity for an endowed company can be explored in two ways. One is to assess what the company would do if they were forced to discard endowments. The second is to assess other company's marketspaces, resources, and capabilities and identify those endowments that you admire. What do they have that you would desire to possess?

If you were forced to discard $25,50,75$ or $100 \%$ of your endowments which ones would they be? Exploration of what you would discard at these various levels can provide insight into what has value and what does not for current operations and potential future products and services. It also highlights endowments that are probably holding the company to incremental innovation for the sake of keeping those endowments utilized. Your endowments should also be assessed from a real options valuation perspective. These options include: option to defer; time to build (option to abandon a buildout); option to alter operating scale; option to abandon; option to switch; growth options; and multiple interaction options (Trigeorgis, 1995). Discarding endowments that have real options value may provide capital for redeployment and make discarding those endowments easier.

Admired marketspaces, resources, or capabilities can be used to create an environment of scarcity since your company does not possess them. When you survey your current, adjacent, or totally new marketspaces or industries which companies do you admire and what about them makes them special? Which of their endowments do you wish your company had? What would you do with those endowments? What would you get rid of to obtain those endowments? The most valuable endowments are knowledge-based capabilities. Can you identify the right knowledge? Do you buy for internal use, develop over time, or outsource those activities which requires that knowledge?

\section{Results}

Radical innovation is required for sustainable survival and future growth of a firm in the global competitive marketspace. The resource base view of the firm along with open innovation and design thinking ideally have potential for generating sustainable competitive advantage. Open innovation and design thinking are more capable of creating radical innovation to produce sustainable competitive advantage than the resources- and capabilities-based approach. However, each of these must overcome the biases inherent in decision making. The firm's endowments in terms of resources, capabilities, and marketspaces are explored in more detail than previous scholarly work. These endowments were qualitatively assessed as to their strength in the providing a firm's competitive advantage and creating and capturing value from radical innovation. Endowment effect biases was then explored, and several firm level and industry level examples were discussed identifying the underlying endowment effect biases. An Innovation / Endowment Effect framework was then created providing insight into the linkages between various endowments and the strength they have in creating radical innovation or, with a strong enough bias, limiting innovation to incremental.

Various exercises were recommended to challenge the company's endowment effect biases and exposes paths to generating new innovative ideas and explores new marketspaces and industries. Several techniques for challenging endowments were presented. Several of these techniques are more challenging to decision makers who have relied upon their endowments to grow the company to current success. However, exploring one exercise at a time will enable decision makers to explore the realm of the radical possible versus staying with the realm of the incremental. 


\section{Conclusions and Future Research}

Endowment Effect has been explored to explain decision maker behavior for pursuing incremental innovation versus radical innovation. The Endowment Effect bias is just one bias that can influence decision maker pursuing innovation. Other biases which influence innovation decisions, in addition to decision making frames and norms, should be explored to offer additional cognitive decision-making explanation of the reduction in radical innovation of large firms. Once identified, techniques should be developed to overcome or decrease the impact of irrational decision making on radical innovation development.

Management practices of resource and capability focused core competencies were also viewed as a triggering event that had decision makers looking at current elements of competitive advantage. Other triggering events such as: the $\mathrm{Y} 2 \mathrm{~K}$ computer uncertainty, 911 terror attacks in the United States, and the 2008-2009 financial crisis that led to US laws in Fraud Enforcement and the Dodd-Frank laws governing financial regulatory systems could have instilled more risk aversion than previous decision makers experienced. These triggering events should be explored when assessing other decisions making biases, norms, and frames that could have influenced a focus on near-term, incremental, low-risk approaches to innovation by larger firms.

This paper initiated the Endowment Effect impact to radical innovation discussion. Future research should be pursued to refine and expand the understand of endowment effect on innovation and creating techniques and process to mitigate the effects of the endowment biases. Further research should also be conducted exploring additional characteristics in the marketspace, resources, and capabilities endowments than have already been identified. Sub-characteristics of each identified endowment characteristic should also be explored to include but not be limited to: global endowment versus local endowment effects; unique combination of endowments; resource, capability, and marketspace strengths in different industries; and age of each endowment characteristic's impact to its strength.

Quantitatively measured strengths of endowments and understand the role of various magnitudes of strength to incremental to radical innovation tipping point decision making. Identifying additional exercises and determine effectiveness in short and long term in the areas of idea creation, value capture, and skill set development for radical innovation teams to ensure continuous idea creation and value capture processes. Additional research should also explore idea creation to value capture transition from an endowment perspective with successful radical innovation creation. Other factors within endowment effect characteristics that should be explored should include influences of endowment usage due to family business effects, corporate culture, or corporate identity.

Endowment effect bias explains but one aspect of decision-making biases against radical innovation. Other biases should be explored and then combined with endowment effect bias to determine the overall impact of various biases on radical innovation creation and value capture. Resource-based view of the firm along with open innovation and design thinking are noteworthy in creating competitive advantage through radical innovation and rational perfect decision making. However, economic behavior theory promotes that people are not perfect decision makers and their various irrationalities have to be considered.

\section{References}

Alexy, O. et al. (2018) 'Surrendering Control to Gain Advantage: Reconciling Openness and the Resource-Based View of the Firm', Strategic Management Journal, 39(6), pp. 1704-1727. 
Amit, R. and Schoemaker, P. J. H. (1993) 'Strategic Assets and Organizational Rent', Strategic Management Journal, 14(1), pp. 33-46.

Armstrong, C. E. and Shimizu, K. (2007) 'A review of approaches to empirical research on the resource-based view of the firm', Journal of Management, 33(6), pp. 959-986.

Banerjee, S. et al. (2019) 'The Dark Side of Power in Innovation Adoption', Journal of Managerial Issues, 31(4), p. 388.

Barney, J. (1991) 'Firm Resources and Sustained Competitive Advantage', Journal of Management, 17(1), pp. 99-120.

Barney, J. B. (1986) 'Strategic Factor Markets: Expectations, Luck, and Business Strategy', Management Science, 32(10), pp. 1231-1241.

Barney, J. B. (1995) 'Looking Inside for Competitive Advantage.', Academy of Management Executive, 9(4), pp. 49-61.

Bogers, M. et al. (2019) 'Strategic Management of Open Innovation: A Dynamic Capabilities Perspective', California Management Review, 62(1), pp. 77-94.

Brown, T. (2009) Change by Design: how design thinking transforms organizations and inspires innovation. New York: Harper Collins.

Brunswicker, S. and Chesbrough, H. (2018) 'The Adoption of Open Innovation in Large Firms: Practices, Measures, and Risks', Research Technology Management, 61(1), pp. 35-45.

Cavaleri, S. and Shabana, K. (2018) 'Rethinking Sustainability Strategies', Journal of Strategy and Management, 11(1), pp. 2-17.

Chesbrough, H. (2003) Open Innovation: The New Imperative for Creating and Profiting from Technology. Cambridge, MA: Harvard Business School Press.

Chesbrough, H., Lettl, C. and Ritter, T. (2018) 'Value Creation and Value Capture in Open Innovation', Journal of Product Innovation Management, 35(6), pp. 930-938.

Christensen, C. M. (1997) The Innovator's Dilemma. Boston: Harvard Business School Publishing.

Christensen, C. M. and Raynor, M. E. (2003) The Innovator's Solution. Boston: Harvard Business School Publishing.

Collis, D. J. and Montgomery, C. A. (2008) 'Competing on Resources', Harvard Business Review, 86(7,8), pp. $140-150$.

Conner, K. R. (1991) 'A Historical Comparison of Resource Based Theory and Five Schools of Thought Within Industrial Organization Economics: Do We Have a New Thoery of the Firm?', Journal of Management, 17(1), pp. 121-154.

Coster, H. and Vengattil, M. (2019) Comcast second-quarter profit beats Wall St., misses on revenue. Reuters.

Damanpour, F. (1992) 'Organizational Size and Innovation', Organization Studies, 13(3), pp. 375-402.

Dierickx, I. and Cool, K. (1989) 'Asset Stock Accumulation and Sustainability of Competitive Advantage', Management Science, 35(12), pp. 1504-1511.

Ettlie, J. E. and Rubenstein, A. H. (1987) 'Firm Size and Product Innovation', Journal of Product Innovation Management, 4(2), pp. 89-108. 
Euchner, J. A. (2010) 'Two Flavors of Open Innovation', Research Technology Management, 53(4), pp. 7-8.

Forés, B. and Camisón, C. (2016) 'Does incremental and radical innovation performance depend on different types of knowledge accumulation capabilities and organizational size?', Journal of Business Research. Elsevier Inc., 69(2), pp. 831-848.

Gallo, C. (2011) The Innovation Secrets of Steve Jobs: Insanely Different Principles for Breakthrough Success. New York: McGraw Hill.

Hopkins, M. S. (2011) 'How to Innovate When Platforms Won't Stop Moving', MIT Sloan Management Review, 52(4), pp. 55-60.

Kahneman, D., Knetsch, J. L. and Thaler, R. H. (1991) 'Anomalies: The Endowment Effect, Loss Aversion, and Status Quo Bias', Journal of Economic Perspectives, 5(1), pp. 193-206.

Kahneman, D. and Tversky, A. (1979) 'Prospect Theory: An Analysis of Decision under Risk', Econometrica, 47(2), pp. 263-291.

Kaissi, A., Shay, P. and Roscoe, C. (2016) 'Hospital systems, convenient care strategies, and healthcare reform', Journal of Healthcare Management, 61(2), pp. 148-163.

Kim, C. W. and Mauborgne, R. (2005) Blue Ocean Strategy: How to Create Uncontested Marketspace and Make Competition Irrelevant. Boston: Harvard Business School Publishing.

Kim, J., Lee, S. J. and Marschke, G. (2009) 'Relation of Firm Size to R\&D Productivity', International Journal of Business and Economics, 8(1), pp. 7-19.

King, A. A. and Baatartogtokh, B. (2015) 'How Useful is the Theory of Disruptive Innovation?', MIT Sloan Management Review, 57(1), pp. 77-90.

Klingebiel, R. and Rammer, C. (2014) 'Resource Allocation Strategy for Innovation Portfolio Management', Strategic Management Journal, 35(2), pp. 246-268.

Knetsch, J. L. (1989) 'The Endowment Effect and Evidence of Nonreversible Indifference Curves', The American Economic Review, 79(5), pp. 1277-1284.

Kovas, A., Looy, B. Van and Cassiman, B. (2015) 'Exploring the Scope of Open Innovation[202F?]: a Bibliometric Review of a Decade of Research', Scientometrics, 104, pp. 951-983.

Liedtka, J. (2015) 'Perspective: Linking Design Thinking with Innovation Outcomes through Cognitive Bias Reduction', Journal of Product Innovation Management, 32(6), pp. 925-938.

Liedtka, J. and Ogilvie, T. (2011) Designing for Growth: a design thinking tool kit for managers. New York: Columbia University Press.

Mote, J. et al. (2016) 'Too big to innovate? Exploring organizational size and innovation processes in scientific research', Science and Public Policy, 43(3), pp. 332-337.

Muller, E. (2020) 'Delimiting disruption: Why Uber is disruptive, but Airbnb is not', International Journal of Research in Marketing. The Author, 37(1), pp. 43-55.

Nason, R. S. and Wiklund, J. (2018) 'An Assessment of Resource-Based Theorizing on Firm Growth and Suggestions for the Future', Journal of Management, 44(1), pp. 32-60.

Patzold, M. (2019) '5G Is Coming Around the Corner [Mobile Radio]', IEEE Vehicular Technology Magazine, 14(1), pp. 4-10.

Peteraf, M. a (1993) 'The Cornerstones of Competitive Advantage: A Resource-Based View', 
Strategic Management Journal, 14(3), pp. 179-191.

PitchBook Data, I. (2019) Venture Monitor Q4 2019.

Porter, M. E. (1985) Competitive Advantage: Creating and Sustaining Superior Performance. New York: The Free Press.

Potts, J. (2016) 'Innovation policy in a global economy', Journal of Entrepreneurship and Public Policy, 5(3), pp. 308-324.

Prahalad, C. . K. . (1993) 'The Role of Core Competencies in the Corporation', Research Technology Management, 36(6), pp. 40-47.

Prahalad, C. . K. . and Hamel, G. (1990) 'The Core Competence of the Corporation', Harvard Business Review, 68(3), pp. 79-91.

Rich, B. R. and Janos, L. (1994) Skunk Works. Little, Brown \& Company.

Rothaermel, F. T. (2020) Tesla, Inc., McGraw Hill Case MHE-FTR-067.

Schumpeter, J. (1975) Capitalism, Socialism, and Democracy. 3rd edn. New York: Harper Perennial.

Senyard, J. et al. (2014) 'Bricolage as a path to innovativeness for resource-constrained new firms', Journal of Product Innovation Management, 31(2), pp. 211-230.

Slowinski, G. et al. (2009) 'Effective Practices for Sourcing Innovation', Research Technology Management, 52(1), pp. 27-34.

Smith, D. K. and Alexander, R. C. (1999) Fumbling the Future: How Xerox invented then ignored, the first personal computer. Lincoln, NE: to Excel.

Smith, R. (2008) 'Harnessing competencies, capabilities and resources', Research Technology Management, 51(5), pp. 47-53.

Van Den Steen, E. (2015) Tesla Motors, Harvard Business School Case 9-714-413.

Tefertiller, A. (2018) 'Media Substitution in Cable Cord-Cutting: The Adoption of Web-Streaming Television', Journal of Broadcasting and Electronic Media. Routledge, 62(3), pp. 390-407.

Thaler, R. (1980) 'Toward a positive theory of consumer choice', Journal of Economic Behavior \& Organization, 39, pp. 36-90.

Trigeorgis, L. (1995) Real Options in Capital Investment: Models, Strategies, and Applications. Westport, CT: Praeger Publishers.

Wernerfelt, B. (1984) 'A Resource-based View of the Firm', Strategic Management Journal, 5(2), pp. $171-180$.

Griggs CRediT Statement: Conceptualization; Methodology; Investigation; Visualization; Data Curation; Writing-Original Draft 


\section{Biographies}

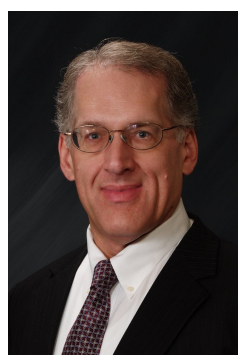

Steven C. Griggs. Steven Griggs earned a B.S in mechanical engineering from the Univ. of Massachusetts, Amherst, an M.S. and PhD in mechanical and aerospace engineering, an MBA in finance and strategy and an M.A. in economics from the Univ. of Texas, Arlington, and a Post-Doctorate in international business and entrepreneurship from the Univ. of Florida, Gainesville. He has over 30 years of aerospace industry experience and seven years of government consulting. He specializes in strategy and technology and product development. He developed ideas, strategies, program plans, and development and led teams. He held various positions in the Lockheed Martin Skunk Works, Northrop Grumman Advanced Technology Design Center, the Boeing Phantom Works, and LTV Advanced Programs. He was been involved in over 45 aircraft programs, developed and transitioned more than 1500 technologies. Dr Griggs is a visiting assistant professor and taught at Oklahoma State University and currently at University of Central Oklahoma. He taught Professional MBA courses in strategy and innovation management disciplines and entrepreneurship for over thirteen years. He is conducting research in strategy, innovation management, corporate entrepreneurship, and decision making. CRediT Statement: Conceptualization; Methodology; Investigation; Visualization; Data Curation; Writing-Original Draft. 